\title{
Using the Defensive Style Questionnaire to evaluate the impact of sex reassignment surgery on defensive mechanisms in transsexual patients Aplicação do Defensive Style Questionnaire para avaliar o impacto da cirurgia de redesignação sexual nos mecanismos de defesa de pacientes transexuaís
}

\author{
Maria Inês Lobato, ${ }^{1}$ Walter José Koff, ${ }^{1,2}$ Tiago Crestana, ${ }^{1}$ Camila Chaves, ${ }^{1}$ \\ Jaqueline Salvador, ${ }^{1}$ Analídia Rodolpho Petry, ${ }^{1}$ Esalba Silveira, ${ }^{1}$ \\ Alexandre Annes Henriques, ${ }^{1}$ Fábio Cervo, ${ }^{1}$ Eduardo Siam Böhme, ${ }^{1}$ Raffael Massuda ${ }^{1}$
}

\begin{abstract}
Objective: To evaluate the impact of sex reassignment surgery on the defense mechanisms of 32 transsexual patients at two different points in time using the Defensive Style Questionnaire. Method: The Defensive Style Questionnaire was applied to 32 patients upon their admission to the Gender Identity Disorder Program, and 12 months after they had undergone sex reassignment surgery. Results: There were changes in two defense mechanisms: anticipation and idealization. However, no significant differences were observed in terms of the mature, neurotic and immature categories. Discussion: One possible explanation for this result is the fact that the procedure does not resolve gender dysphoria, which is a core symptom in such patients. Another aspect is related to the early onset of the gender identity disorder, which determines a more regressive defensive structure in these patients. Conclusion: Sex reassignment surgery did not improve the defensive profile as measured by the Defensive Style Questionnaire.
\end{abstract}

Descriptors: Defense mechanisms; Surgery; Transsexualism; Gender identity; Questionnaires

\begin{abstract}
Resumo
Objetivo: Avaliar o efeito da cirurgia de redesignação sexual nos mecanismos de defesa de 32 pacientes transexuais em dois momentos distintos usando o Defensive Style Questionnaire. Método: O Defensive Style Questionnaire foi aplicado a 32 pacientes quando ingressaram no Programa de Transtorno de Identidade de Gênero e 12 meses após a cirurgia de redesignação sexual. Resultados: Houve modificações em dois mecanismos de defesa: antecipação e idealização; porém, sem mudanças significativas nos fatores maduro, neurótico e imaturo. Discussão: Uma possibilidade para esse resultado é o fato de a intervenção cirúrgica não resolver a disforia de gênero (principal sintoma desses pacientes). Outro aspecto está relacionado com o fato de o transtorno de identidade de gênero ser instalado precocemente, o que determina uma estrutura defensiva mais regressiva para esses pacientes. Conclusão: A cirurgia de redesignação sexual não foi capaz de modificar o padrão dos mecanismos de defesa medidos pelo Defensive Style Questionnaire.
\end{abstract}

Descritores: Mecanismos de defesa; Cirurgia; Transexualismo; Identidade de gênero; Questionários

1 Gender Identity Disorder/Transsexualism Program (PROTIG), Hospital de Clínicas de Porto Alegre (HCPA), Porto Alegre (RS), Brazil
2 School of Medicine, Universidade Federal do Rio Grande do Sul (UFRGS), Porto Alegre (RS), Brazil

Gender Identity Disorder/Transsexualism Program (PROTIG) of Hospital de Clínicas de Porto Alegre (HCPA), Universidade Federal do Rio Grande do Sul (UFRGS), Porto Alegre (RS), Brazil.

Correspondence

Maria Inês Lobato

Rua 24 de Outubro, 340/22, Independência

90510-000 Porto Alegre, RS, Brazil

Tel.: (+55 51) 3311-7891

E-mail: mlupo@pro.via-rs.com.br 


\section{Introduction}

Transsexualism (ICD-10)ำ Gender Identity Disorder (DSM-IV-TR) ${ }^{2}$ is characterized by a strong and persistent cross-gender identification that affects different aspects of behavior. In a subgroup of patients, it leads to the pursuit of medical treatment to modify primary and secondary sex characteristics by means of, for example, hormone therapy, vaginoplasty or phalloplasty. ${ }^{3-6}$

For eight years, the Gender Identity Disorder/Transsexualism Program (PROTIG) of the Hospital de Clínicas de Porto Alegre, Universidade Federal do Rio Grande do Sul (UFRGS), Brazil, has been providing public assistance to transsexual patients. ${ }^{3,4}$ The program offers patients psychosocial support, medical assistance and family guidance, and refers patients to sex reassignment surgery when indicated.

The psychological impact of this condition is usually underestimated both in terms of the understanding of its effects on the personality of each individual, as well as in terms of its association with high rates of psychiatric comorbidities. ${ }^{7}$

Psychological defense mechanisms (PDM) are indicators of how individuals usually deal with their conflicts and provide parameters to understand how personality is organized. According to the DSM-IV-TR, a defense is an automatic psychological process that protects the individual against anxiety, internal or external dangers, or stressors. PDM are hierarchically classified into three defense levels, in accordance with psychodynamic theory and according to maturity level: mature, neurotic, and immature..$^{8-10}$ In this study, PDM were evaluated using the Brazilian Portuguese version of the Defensive Style Questionnaire (DSQ), a self-report questionnaire featuring 40 questions and which was previously validated by Blaya et al. ${ }^{11-15}$

Our literature search on Medline using the terms "defense mechanism", "transsexualism", and "gender identity disorder" did not yield any studies on defense mechanisms to evaluate transsexual patients using the DSQ. Moreover, the diagnosis and management of personality disorders during preoperative counseling of transsexual patients has prognostic importance. Therefore, the purpose of this study was to evaluate the effect of surgical interventions on the defense mechanisms of 32 patients at two time points, i.e., admission into the PROTIG program and one year after sex reassignment surgery.

\section{Method}

This open clinical trial was conducted by applying the DSQ to patients at two time points: TO- when they joined the Gender Identity Disorder Program (PROTIG); and T1- 12 months after sex reassignment surgery (SRS). Individuals with psychotic disorders, mental retardation, substance dependence or younger than 21 years of age are not admitted into the PROTIG program. Those who are admitted are required to participate in supportive group therapy sessions lasting one hour and held on a weekly or biweekly basis for at least two years. During these sessions, which are conducted by a psychiatrist and a social worker, questions about SRS and issues revolving around their day-to-day lives such as interpersonal relationships, employment and discrimination are addressed. Each group is comprised of about 14 patients, all of whom with a diagnosis of transsexualism; their primary diagnoses, possible comorbidities and psychosocial status are regularly reevaluated. When necessary, patients are referred to individual psychotherapy. ${ }^{3,4}$

The DSQ evaluates 20 defense mechanisms that are divided into three categories: mature, neurotic and immature. Each item is evaluated using a 10-point Likert-like scale (from 1 to 9). Individual defense scores are calculated as the mean between the two items corresponding to each defense mechanism, and the scores for each category are calculated as the mean between all scores of the defense mechanisms belonging to that category.

The questionnaire was answered by 32 patients enrolled in the PROTIG program who agreed to participate in the study, signed an informed consent term and met the inclusion criteria set by the PROTIG mental health team i.e., diagnosis of transsexualism (ICD-10)/gender identity disorder (DSM-IV-TR) and minimum age of 16 years.

PROTIG provides care to 154 patients. By the time this report was written, 48 SRS had been performed. Two patients refused to participate in the study and 14 were lost to follow-up.

Demographic and defense profile variables were described as means and standard deviations. The SPS 12.0 software was used for statistical analysis and the Student's T-Test was employed for comparison purposes.

The study was approved by the Ethics Committee of the of Hospital de Clínicas de Porto Alegre (98-319).

\section{Results}

Table 1 describes the characteristics of patients in the sample $(n=32)$. The age range of the 32 patients included in the study varied between 16 to 54 years and all patients were male-to-female transsexuals. The age at which cross-gender play started ranged from 2 to 8 years (mean $=5.46$ years), and cross-dressing from 8 to 26 years (mean $=15.61$ years). The age at which hormone therapy was initiated ranged from 11 to 42 years, and the age at which patients had their first sexual intercourse ranged from 8 to 26 years. Table 2 shows results obtained from the DSQ.

The comparison between study participants and those who refused to participate at TO did not reveal any significant differences; therefore, there was no internal validity problem.

Statistically significant differences were found for two mechanisms after SRS: anticipation ( $p=0.006)$ and idealization $(p=0.05)$. No significant differences were found for the three categories: mature defenses $(p=0.184)$, neurotic defenses $(p=0.264)$ and immature defenses $(p=0.945)$.

\section{Discussion}

Previous studies using the DSQ have shown that, in the presence of axis I disorders, the functioning pattern is associated with immature defenses. Following the clinical improvement of these conditions, a change in defense style into more neurotic or mature defenses has been observed. ${ }^{16-19}$

\section{Table 1 - Descriptive statistics}

\begin{tabular}{|c|c|c|c|c|c|}
\hline & $\mathbf{n}$ & Minimum & Maximum & Mean & SD \\
\hline Age & 32 & 16 & 54 & 31.66 & 10.082 \\
\hline Age - cross-gender play & 13 & 2 & 8 & 5.46 & 1.664 \\
\hline Age - cross-dressing & 31 & 8 & 26 & 15.61 & 5.090 \\
\hline Age - hormone therapy & 32 & 11 & 42 & 18.97 & 6.528 \\
\hline Age $-1^{\text {st }}$ sexual relation & 29 & 8 & 26 & 15.62 & 3.868 \\
\hline
\end{tabular}


Table 2 - Test statistics

\begin{tabular}{lccc}
\hline Defense mechanism & Before & After & p-value \\
\hline Sublimation & $6.11 \pm 2.15$ & $5.42 \pm 1.99$ & 0.131 \\
Humor & $6.19 \pm 2.34$ & $6.05 \pm 2.45$ & 0.744 \\
Anticipation & $6.83 \pm 1.90$ & $5.81 \pm 2.03$ & 0.003 \\
Rationalization & $5.921 \pm 1.81$ & $5.32 \pm 1.35$ & 0.203 \\
Suppression & $5.44 \pm 2.06$ & $5.56 \pm 2.05$ & 0.787 \\
Mature defenses & $5.99 \pm 1.23$ & $5.69 \pm 1.00$ & 0.327 \\
Undoing & $4.97 \pm 2.23$ & $4.94 \pm 2.41$ & 0.950 \\
Pseudoaltruism & $5.92 \pm 2.11$ & $5.70 \pm 2.01$ & 0.632 \\
Idealization & $4.48 \pm 2.43$ & $3.67 \pm 2.16$ & 0.053 \\
Reaction formation & $5.17 \pm 2.44$ & $4.59 \pm 2.22$ & 0.306 \\
Neurotic defenses & $5.137 \pm 1.57$ & $4.73 \pm 1.55$ & 0.182 \\
Projection & $2.78 \pm 2.49$ & $2.39 \pm 1.82$ & 0.449 \\
Passive aggression & $2.33 \pm 1.74$ & $2.31 \pm 1.32$ & 0.968 \\
Acting out & $3.39 \pm 2.20$ & $3.98 \pm 2.19$ & 0.105 \\
Isolation & $3.31 \pm 2.17$ & $3.59 \pm 2.20$ & 0.519 \\
Devaluation & $4.61 \pm 2.05$ & $4.31 \pm 1.90$ & 0.474 \\
Autistic fantasy & $3.44 \pm 2.61$ & $3.08 \pm 2.34$ & 0.530 \\
Denial & $3.94 \pm 2.69$ & $3.94 \pm 1.95$ & 1.000 \\
Displacement & $2.86 \pm 1.92$ & $3.12 \pm 2.13$ & 0.465 \\
Dissociation & $3.81 \pm 2.00$ & $3.08 \pm 1.83$ & 0.082 \\
Splitting & $4.94 \pm 2.06$ & $5.06 \pm 2.17$ & 0.719 \\
Somatization & $3.94 \pm 2.09$ & $3.48 \pm 2.19$ & 0.335 \\
Immature defenses & $3.58 \pm 1.28$ & $3.49 \pm 1.15$ & 0.708 \\
\hline
\end{tabular}

The literature and clinical practice show that SRS significantly improves the lives of transsexual patients. ${ }^{5,20,21}$ In an attempt to translate this improvement into objective parameters, we employed the DSQ to investigate whether there are changes in the defensive styles of patients following SRS.
In this study, the administration of the DSQ did not reveal changes in defensive style one year after SRS. One possible explanation for this is that despite the clinical improvement and decreased psychological suffering achieved with SRS, the procedure does not resolve gender dysphoria (a core symptom in these patients). Another aspect is related to the early onset of gender identity disorder, which, differently from axis I disorders starting in adult life, leads to a more regressive defensive structure in these patients.

One of the limitations of this study was that a structured axis II diagnosis was not made before inclusion and, therefore, factors such as severe psychiatric comorbidities (personality disorders) could not be evaluated. Personality disorders are common among transsexual patients, ${ }^{22}$ who may also show a persistent pattern consisting of immature or neurotic defensive behaviors. Moreover, maybe one year post op is just not long enough for one to witness changes since it is still considered to be a time for adaptation and postoperative recovery.

The size of our sample was similar to that of other studies reporting changes in defense mechanisms in patients with other disorders. Therefore, it seems that our negative results cannot be attributed to a type II error.

\section{Conclusion}

Sex reassignment surgery did not improve the defensive profile of transsexual patients as measured by the DSQ.

\section{Acknowledgments}

The authors would like to acknowledge the Psychiatry and Urology Services of Hospital de Clínicas de Porto Alegre and the School of Medicine of Universidade Federal do Rio Grande do Sul for their assistance.

\section{Disclosures}

\begin{tabular}{|c|c|c|c|c|c|c|c|}
\hline Writting group member & Employment & $\begin{array}{l}\text { Research } \\
\text { grant }^{1}\end{array}$ & $\begin{array}{c}\text { Other research grant or } \\
\text { medical continuous } \\
\text { education }\end{array}$ & $\begin{array}{l}\text { Speaker's } \\
\text { honoraria }\end{array}$ & $\begin{array}{c}\text { Ownership } \\
\text { interest }\end{array}$ & $\begin{array}{l}\text { Consultant/ } \\
\text { Advisory } \\
\text { board }\end{array}$ & Other $^{3}$ \\
\hline Maria Inês Lobato & HCPA & - & - & - & - & - & - \\
\hline \multirow[t]{2}{*}{ Walter José Koff } & HCPA & - & - & - & - & - & - \\
\hline & UFRGS & & & & & & \\
\hline Tiago Crestana & $\mathrm{HCPA}$ & - & - & - & - & - & - \\
\hline Camila Chaves & $\mathrm{HCPA}$ & - & - & - & - & - & - \\
\hline Jaqueline Salvador & HCPA & - & - & - & - & - & - \\
\hline Analídia Rodolpho Petry & HCPA & - & - & - & - & - & - \\
\hline Esalba Silveira & HCPA & - & - & - & - & - & - \\
\hline Alexandre Annes Henriques & HCPA & - & - & - & - & - & - \\
\hline Fábio Cervo & HCPA & - & - & - & - & - & - \\
\hline Eduardo Siaim Böhme & $\mathrm{HCPA}$ & - & - & - & - & - & - \\
\hline Raffael Massuda & HCPA & - & - & - & - & - & - \\
\hline $\begin{array}{l}\text { * Modest } \\
\text { ** Significant } \\
\text { *** Significant. Amounts given } \\
\text { Note: HCPA = Hospital de Clín } \\
\text { For more information see Inst }\end{array}$ & de Porto Alegr & RGS = Univ & $\begin{array}{l}\text { for research in which the auth } \\
\text { de Federal do Rio Grande do }\end{array}$ & has participatic & 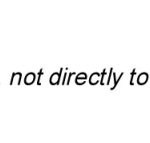 & & \\
\hline
\end{tabular}

References

1. Organização Mundial da Saúde. Classificação de transtornos mentais e de comportamento da CID-10: descrições clínicas e diretrizes diagnósticas. Porto Alegre: Artmed; 1995.

2. Associação Americana de Psiquiatria. Manual diagnóstico e estatístico de transtornos mentais (DSM-IV). 4a ed. Porto Alegre: Artmed; 1995.
3. Lobato MI, Henriques AA, Ghisolfi E, Schestatsky SS. Aspectos da abordagem psiquiátrica ao transexualismo (CID-X) - transtorno de identidade de gênero (DSM-IV). Rev Psiquiatr RS. 2001;23(2): 106-10.

4. Lobato MI, Henriques AA, Ghisolfi ES, Kegel S, Schestatsky G, Schestatsky SS. Transexualismo: uma revisão. J Bras Psiquiatr. 2001;50(11/12):379-88. 
5. Cohen-Kettenis P, Gooren LJ. Transsexualism: a review of etiology, diagnosis and treatment. J Psychosom Res. 1999;46(4):315-33.

6. Roberto LG. Issues in diagnosis and treatment of transsexualism. Arch Sex Behav. 1983;12(5):445-73.

7. Corina B, Borges G, Medina-Mora ME. DSM-IV personality disorders in Mexico: results from a general population survey. Rev Bras Psiquiatr. 2008:30(3):227-34.

8. Vaillant GE. Ego mechanisms of defense and personality psychopathology. J Abnorm Psychol. 1994;103(1):44-50.

9. Paris J, Zweig-Frank H, Bond M, Guzder J. Defense styles, hostility, and psychological risk factors in male patients with personality disorders. J Nerv Ment Dis. 1996;184(3):153-8.

10. Holi MM, Sammallahti PR, Aalberg VA. Defense styles explain psychiatric an empirical study. J Nerv Ment Dis. 1999;187(11): 654-60.

11. Blaya C, Kipper L, Heldt E, Isolan L, Ceitlin LH, Bond M, Manfro GG. Brazilian-Portuguese version of the Defense Style Questionnaire (DSQ-40) for defense mechanisms measure: a preliminary study. Rev Bras Psiquiatr. 2004;26(4):255-8.

12. Bond M, Gardiner ST, Christian J, Sigel JJ. Empirical study of selfrated defense styles. Arch Gen Psychiatry. 1983;40(3):333-8.

13. Andrews G, Pollock $C$, Stewart G. The determination of defense style by questionnaire. Arch Gen Psychiatry. 1989;46(5):455-60.

14. Bond M, Perry C, Gantier M, Goldenberg M, Oppenheimer J, Simand J. Validating the self-report of defense styles. J Personal Disord. 1989;3(2):1-12.

15. Andrews G, Singh M, Bond M. The Defense Style Questionnaire. J Nerv Ment Dis. 1993;181(4):246-56.

16. Bond M, Perry JC. Long-term changes in defense styles with psychodynamic psychotherapy for depressive, anxiety, and personality disorders. Am J Psychiatry. 2004;161(9):1665-71.

17. Heldt E, Blaya C, Kipper L, Salum GA, Otto MW, Manfro GG. Defense mechanisms after brief cognitive-behavior group therapy for panic disorder: one-year follow-up. J Nerv Ment Dis. 2007; 195(6):540-3.

18. Akkerman K, Carr V, Lewin T. Changes in ego defenses with recovery from depression. J Nerv Ment Dis. 1992;180(10):634-8.

19. Kipper L, Blaya C, Teruchkin B, Heldt E, Isolan L, Mezzomo K, Bond M, Manfro GG. Evaluation of defense mechanisms in adult patients with panic disorder: Before and after treatment. J Nerv Ment Dis. 2005;193(9):619-24.

20. Bodlund O, Kullgren G. Transsexualism - general outcome and prognostic factors: a five-year follow-up study of nineteen transsexuals in the process of changing sex. Arch Sex Behav. 1996;25(3): 303-16.

21. Lobato MI, Koff WJ, Manenti C, da Fonseca Seger D, Salvador J, da Graça Borges Fortes M, Petry AR, Silveira E, Henriques AA. Followup of sex reassignment surgery in transsexuals: a Brazilian cohort. Arch Sex Behav. 2006;35(6):711-5.

22. Cole CM, O'Boyle M., Emory LE, Meyer WJ 3rd. Comorbidity of gender dysphoria and other major psychiatric diagnoses. Arch Sex Behav. 1997;26:26(1):13-26. 